\title{
Urea transporter physiology studied in knockout mice
}

\author{
Xuechen $\mathrm{Li}^{1}$, Guangping Chen ${ }^{2 *}$ and Baoxue Yang ${ }^{1 *}$ \\ ${ }^{1}$ Department of Pharmacology, School of Basic Medical Sciences, Peking University, and Key Laboratory of Molecular Cardiovascular Sciences, Ministry of \\ Education, Beijing, China \\ ${ }^{2}$ Renal Division, Emory University School of Medicine, Atlanta, GA, USA
}

Edited by:

Nuria M. Pastor-Soler, University of Pittsburgh School of Medicine, USA

\section{Reviewed by:}

Arohan Subramanya, University of

Pittsburgh School of Medicine, USA

Heddwen Brooks, University of

Arizona, USA

\section{${ }^{*}$ Correspondence:}

Guangping Chen, Department of

Medicine, School of Medicine, Emory

University, Atlanta, GA 30322, USA.

e-mail: gchen3@emory.edu;

Baoxue Yang, Department of

Pharmacology, School of Basic

Medical Sciences, Peking University,

38 Xueyuan Lu, Haidian District,

Beijing 100191, China.

e-mail:baoxue@bjmu.edu.cn
In mammals, there are two types of urea transporters; urea transporter (UT)-A and UT-B. The UT-A transporters are mainly expressed in kidney epithelial cells while UT-B demonstrates a broader distribution in kidney, heart, brain, testis, urinary tract, and other tissues. Over the past few years, multiple urea transporter knockout mouse models have been generated enabling us to explore the physiological roles of the different urea transporters. In the kidney, deletion of UT-A1/UT-A3 results in polyuria and a severe urine concentrating defect, indicating that intrarenal recycling of urea plays a crucial role in the overall capacity to concentrate urine. Since UT-B has a wide tissue distribution, multiple phenotypic abnormalities have been found in UT-B null mice, such as defective urine concentration, exacerbated heart blockage with aging, depression-like behavior, and earlier male sexual maturation. This review summarizes the new insights of urea transporter functions in different organs, gleaned from studies of urea transporter knockout mice, and explores some of the potential pharmacological prospects of urea transporters.

Keywords: knock out mouse, urea transport, urea transporter inhibitor, urinary concentrating mechanism
Urea, a small highly polar molecule $(\mathrm{MW} \approx 60 \mathrm{Da})$, is the major end product of nitrogen metabolism. Urea is generated from the ornithine cycle in liver, and is ultimately excreted by the kidney representing $90 \%$ of total nitrogen in urine. The remaining $10 \%$ waste nitrogen is largely composed of uric acid and ammonium (Fenton, 2008).

Urea has been thought to cross the cell membrane by simple diffusion for 30 years. However, a permeability study revealed that urea crossing artificial lipid bilayers is actually very low, only at $4 \times 10^{-6} \mathrm{~cm} / \mathrm{s}$ (Gallucci et al., 1971). Considering the high concentration of urea in human $(285 \mathrm{mmol} / \mathrm{L})$, rat $(700 \mathrm{mmol} / \mathrm{L})$, and mouse $(1800 \mathrm{mmol} / \mathrm{L})$ urine, the amount of urea in the urine should inevitably cause osmotic diuresis in the renal collecting ducts. This scenario does not happen in vivo. Gamble et al. (1934) discovered that kidneys have an ability to excrete high concentrations of urea without taking away corresponding water, indicating that simple diffusion was not the only way for urea across the membrane. Direct physiological evidence from a renal tubular perfusion experiment by Sands and Knepper (1987) demonstrated the existence of urea permeability in the terminal inner medullar collecting duct that was higher than the level accounted for with simple diffusion. This led to the discovery of the facilitative urea transporters (UTs). You et al. (1993) cloned the first facilitative UT.

\section{GENETIC CHARACTERISTICS OF UREA TRANSPORTERS}

The two UT subfamilies of UT-A and UT-B are encoded by Slc14a2 and Slc14al gene, respectively. In human, both UT genes are located on chromosome 18 (Fenton et al., 1999; Smith and Fenton, 2006). The UT-A family has six members, UT-A1 through UT-A6, and at least two distinct promoters, UT-A $\alpha$ and UT-A $\beta$ (Timmer et al., 2001; Bagnasco, 2003). UT-A $\alpha$ is in the $5^{\prime}$-flanking region of
UT-A gene (Timmer et al., 2001) and responsible for UT-A1, UTA3, and UT-A4 gene transcription. Structurally, these three forms share an identical $\mathrm{N}$-terminal part but are diverse in C-terminal ends. The UT-A1 stop codon is located in exon 24, the last exon of the UT-A gene, which makes UT-A1 the largest form in this family (Fenton et al., 2002b). The UT-A3 stop codon is in exon 13. UT-A1 does not possess exon 13 avoiding early termination of UT-A1 translation (You et al., 1993). UT-A4 gene is only identified by RT-PCR due to its low abundance in kidney (Smith et al., 2004). The gene encoding UT-A2 possesses a start site in exon 14 that is distinct from other members in the family. UT-A2 shares an identical C-terminal site with UT-A1 and UT-A4 (Karakashian et al., 1999). UT-A2 is regulated by the UT-A $\beta$ promoter in intron 13 (You et al., 1993). UT-A5 is reported in mouse testis and has the identical C-terminus of UT-A3 (Olives et al., 1994). In human, UT-A6 is identified in colonic cells and is the smallest member of UT-A family with 216 amino acids (Bagnasco, 2003).

Urea transporter-B is the only transcription product of Slc14A1 gene in human, mouse, and rat. In 2009, the crystal structure of UT-B was determined (Levin et al., 2009). The membranespanning pore consisting of two halves of the protein has a filter to select proper molecules to pass. To compensate for the energy used in dehydration, there are hydrogen bonds between urea and oxygen atoms in the principal-chain and side-chain of the UTB molecule, as well as interactions between $\alpha$-helix dipoles and amide- $\pi$ (Levin et al., 2009).

\section{UT TISSUE DISTRIBUTION AND REGULATION}

Urea transporter-A1 is distributed in the apical membrane of the middle and terminal inner medullary collecting duct (IMCD) cells (Figure 1; Shayakul and Hediger, 2004). The large 


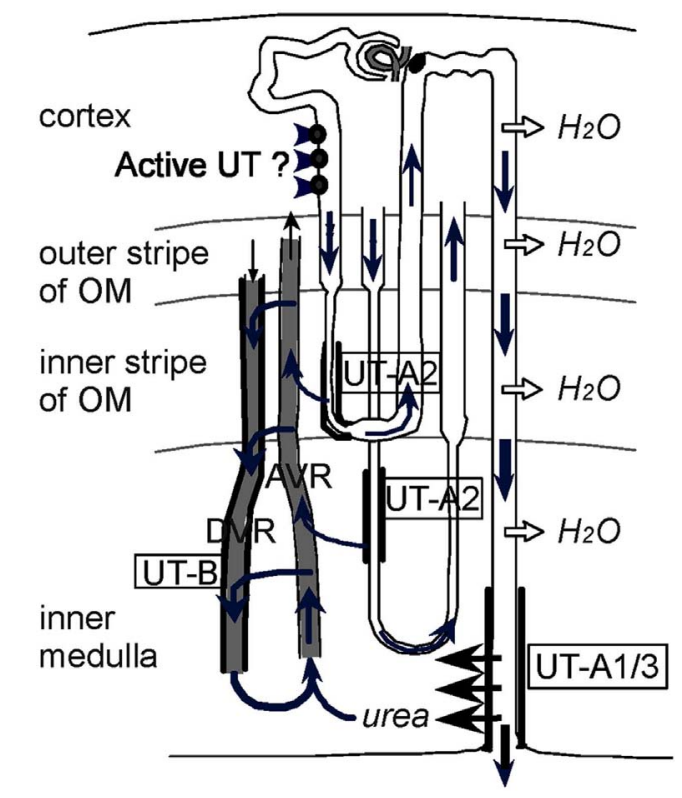

FIGURE 1 | Diagram depicting the vascular and tubular routes of urea recycling within the kidney. A short and a long-loop of Henle are depicted within the four kidney zones, along with a descending vasa recta (DVR) and an ascending vasa recta (AVR). OM is defined as outer medulla. In normal mice, concentrated urea is delivered to the tip of the papilla by the terminal part of the collecting ducts expressing the vasopressin-regulated urea transporters UT-A1/3. Urea is taken up by ascending blood (plasma and red blood cells) in AVR, and a significant fraction of it is returned to the IM by being reintroduced either in the DVR (expressing UT-B) or in the descending thin limbs of Henle's loops (expressing UT-A2). Reproduced from Lei et al. (2011).

intracellular hydrophilic loop of UT-A1 contains several PKA and PKC consensus phosphorylation sites (Shayakul and Hediger, 2004). Consistently, cAMP and cAMP agonists, such as vasopressin, forskolin, and IBMX have been reported to stimulate UT-A1 urea transport activity (Frohlich et al., 2006). In addition, hyperosmolarity- and angiotensin II-stimulated UT-A1 activation is by a PKC mediated pathway (Kato et al., 2000; Wang et al., 2010; Klein et al., 2012). Lithium can stimulate UT-A1 activity but does not activate the cAMP signaling pathway (Frohlich et al., 2008).

Urea transporter-A2 is expressed in the thin descending limbs (TDL) of Henle's loop, containing short-loop nephrons in the inner stripe of the outer medulla and long-loop nephrons in the base of the inner medulla (IM; Wade et al., 2000). UT-A2 cannot only be acutely stimulated by cAMP, vasopressin, or increased intracellular calcium (Potter et al., 2006), but is also chronically up-regulated by vasopressin (Wade et al., 2000). Rat UT-A3 has been reported to localize IMCD cells in the apical membrane as well as intracellularly (Terris et al., 2001). However in mice, it is also expressed in the basolateral membrane of IMCD cells (Stewart et al., 2004). UT-A3 is sensitive to acute stimulation by the cAMP signaling pathway (Shayakul and Hediger, 2004). Chronic vasopressin infusion can increase UT-A3, as well as UT-A1, mRNA, and protein expression (Cai et al., 2010). UT-A4 is expressed in the renal IM in rat but its exact distribution is unclear. In vitro studies show that UT-A4 is also stimulated by the cAMP signaling pathway (Karakashian et al., 1999). UT-A5 is exclusively expressed in the peritubular myoid cells of the outermost layer of the seminiferous tubules (SMTs) in testes (Fenton et al., 2000, 2002a). UT-A6 is only characterized in human colonic mucosa. Although lacking a common PKA phosphorylation consensus site, UT-A6 is sensitive to cAMP and cAMP agonists (Bagnasco, 2003). UT-A transcripts are also detected in brain, heart, and liver (Fenton et al., 2002b), but the function and characteristic of the extra-renal UT-A has been less explored.

Urea transporter-B has a wide tissue distribution. In the kidney, it is located in the endothelial cells of descending vasa recta (DVR; Pallone, 1994; Tsukaguchi et al., 1997; Xu et al., 1997). In brain (Couriaud et al., 1996) UT-B mainly expresses in astrocytes, ependymal cells, as well as subgroups of neurons in dorsal root ganglia and the inferior colliculus, and cells in the anterior pituitary gland (Berger et al., 1998). The erythrocyte membrane contains abundant UT-B (Olives et al., 1994), which not only mediates rapid movement of urea across red blood cells, but also serves as a Kidd (JK) antigen (Olives et al., 1995; Timmer et al., 2001). In addition, UT-B is found in colon (Inoue et al., 2004), sertoli cells in testis (Fenton et al., 2002a), heart, liver, spleen, lung, stomach (Lucien et al., 2005), and epithelial cells in urinary tract including bladder, ureter, and pelvis lumens (Spector et al., 2004). UT-B is down-regulated by dDAVP, an agonist of the type II vasopressin receptor (Trinh-Trang-Tan et al., 2002).

Urea transporter-A expression is observed early in 1-day-old neonates while UT-B is not detected until the fetus is 20 days old (Kim et al., 2002). UT-A2 expression is up-regulated in UT-B null mice (Klein et al., 2004). The urea transport activity of all six UT-A members and UT-B is inhibited by phloretin (Olives et al., 1994; Klein et al., 2004).

\section{PHYSIOLOGICAL ROLE OF UTS KIDNEY: URINE CONCENTRATING MECHANISM}

Urine concentration in the kidney is a complicated process involving many solutes, such as urea, $\mathrm{Na}^{+}, \mathrm{K}^{+}, \mathrm{Cl}^{-}$, etc. (Chou and Knepper, 1989). Of all these solutes, urea plays a key role by recycling in the renal medulla (Sands, 2002).

Figure 1 illustrates the intrarenal urea recycling (Lei et al., 2011). As urine flows along the collecting duct, water is absorbed through water channels (AQPs), resulting in a high urea concentration in the terminal IMCD. There, the urea is rapidly reabsorbed by UTs UT-A1 and UT-A3. This process is regulated by vasopressin and is important to maintain high urea concentration in inner medullary interstitium and to set up the intrarenal osmotic gradient. The reabsorbed urea enters ascending vasa recta (AVR) where the endothelium has micropores permeable to urea. Urea is transferred from AVR to DVR through UT-B in a countercurrent exchange that helps to preserve the urea concentration gradient in IM (Yang and Bankir, 2005). In addition, UT-A2 expressed in TDL also mediates urea transport from the lumen to the interstitium, where the urea eventually goes back to the IM through DVR. The entire urea recycling is carried out in concert by UT-A1, UT-A3 in terminal IMCD, UT-A2 in TDL, and UT-B in DVR, and enables the kidney to establish the hyperosmotic gradient in the IM. 
The vital roles of UTs in intrarenal urea recycling and the urine concentrating mechanism have been confirmed by knockout mouse models. In UT-B null mice, the urea clearance rate is reduced by $25 \%$ while the urea concentration increases by $30 \%$ and urea concentration in urine decreases by $35 \%$. The UT-B null mice demonstrate higher urine output than wild-type mice (Figure 2; Bankir et al., 2004; Yang and Bankir, 2005; Lei et al., 2011). Moreover, the urinary urea concentration and the osmolality are not elevated in response to acute urea load (Figure 3), indicating that urea cannot be efficiently concentrated and water cannot be preserved in the absence of the UT-B. UT-B deletion causes a urea-selective urinary concentrating defect (Yang et al., 2002; Yang and Bankir, 2005). This fact could prove very promising in developing diuretics that specifically inhibit UT-B activity. Of note, UT-B expressed on the erythrocyte membrane also significantly contributes to the urine concentrating mechanism, which will be discussed later.

Urea transporter-A2 null mice are not different from wild-type mice in urine concentrating ability under normal conditions. A reduction in urea accumulation in the IM was observed only when a low-protein diet was applied, which reduced urea production (Yang et al., 2002). UT-A2 was thought to mediate urea exit from AVR to TDL. However, comparing the phenotype between UT-B

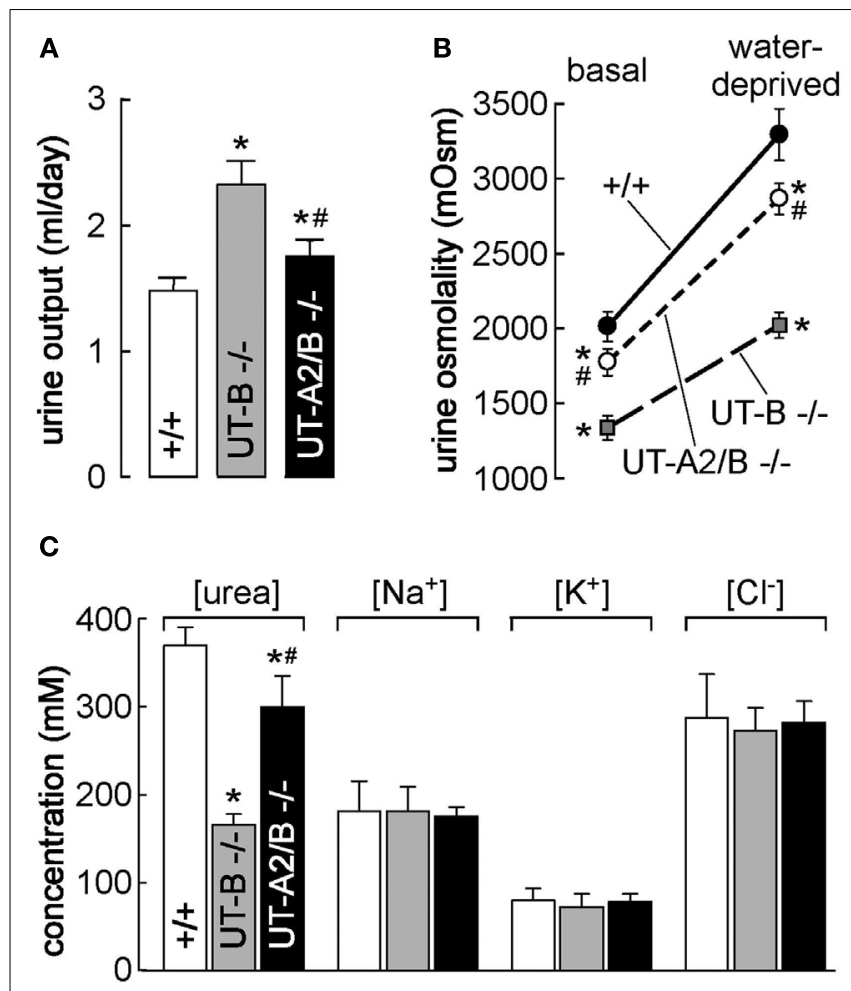

FIGURE 2 | Urea transporter-B knockout and UT-A2/UT-B knockout mouse models. (A) Twenty-four hours urine output in mice of indicated genotype. (B) Urine osmolality measured in mice given free access to food and water (basal) and after an 18-h water deprivation (right; $n=6$ mice/group, means $\pm \mathrm{SE},{ }^{*} p<0.01$ compared with WT mice. ${ }^{*} p<0.01$ compared with UT-B KO mice). (C) Urea concentration, sodium concentration, potassium concentration, and chloride concentration in homogenized IM (means $\pm \mathrm{SE}, n=6$. * $p<0.01$ compared with WT mice. ${ }^{\#} p<0.01$ compared with UT-B KO mice). Reproduced from Lei et al. (2011). null mice and UT-A2 null mice, the previously proposed role of UT-A2 needs to be further assessed (Uchida et al., 2005). The UT-A2 and UT-B double knockout (UT-A2/B-/-) mouse is a good model for determining the role of UT-A2 by comparing UTA2/B-/- and UT-B-/- (Lei et al., 2011). As shown in Figure 2, urine output, urine osmolality, and urea concentration in IM at both basal and water-deprived conditions in UT-A2/B-/- mice were between those in UT-B-/- mice and wild-type mice. The phenotype of UT-A2/B-/ - mice after acute urea load was also between that of UT-B-/- mice and wild-type mice (Figure 3 ). These results show that UT-A2 and UT-B contribute to urea cycling in an opposing way, that is, UT-A2 mediates urea transport from the lumen to the interstitium. This hypothesis requires an outward-directed concentration gradient from TDL to the interstitium, which might be provided by active secretion to the pars recta. Further studies are needed to clarify this hypothesis.

Urea transporter-A1 and UT-A3 double knockout (UTA1/3-/-) mice were generated by gene targeting strategy (Fenton et al., 2004). UT-A1/3-/- mice had significantly higher urine output and water intake than wild-type mice in high-protein and normal-protein feeding conditions but not with low-protein feeding. After an 18-h water deprivation, reduced urine output was observed in UT-A1/3-/- in low-protein fed mice but not in mice under high-protein and normal-protein conditions (Fenton and Knepper, 2007; Fenton, 2008). These findings suggest that the diuresis that occurs in UT-A1/3-/- mice is due to the high urea concentration accumulated in the lumen, which supports the hypothesis that UT-A1 and UT-A3 mediate the rapid urea transport from the lumen of the IMCD to the interstitium. Fenton has an excellent review discussing the UT-A1/A3 knockout mouse (Fenton and Knepper, 2007).

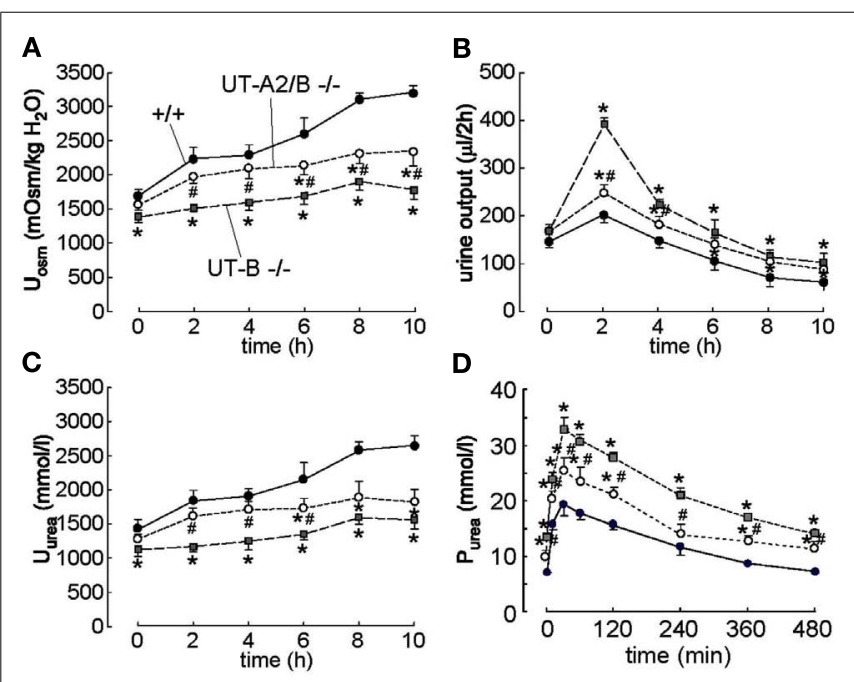

FIGURE 3 | Effect of acute urea loading on urinary concentrating activity and renal handling of urea in WT, UT-B KO, and UT-A2/B KO mice. Three-hundred micromolar urea were injected intraperitoneally just after the first $2 \mathrm{~h}$ urine collection (time 0 ), and urine was then collected for four more $2 \mathrm{~h}$ periods. (A) Urine osmolality $\left(U_{\text {osm }}\right)$. (B) Urine output. (C) Urine urea concentration $\left(U_{\text {urea }}\right)$. (D) Plasma urea concentration $P_{\text {urea }}$. Values are expressed as means $\pm \mathrm{SE}, n=6 /$ group. ${ }^{*} p<0.01$ compared with WT mice, ${ }^{*} p<0.01$ compared with UT-B KO mice. Reproduced from Lei et al. (2011). 


\section{ERYTHROCYTES}

Erythrocyte membranes have high urea permeability, which is $1.1 \pm 0.2 \times 10^{-5} \mathrm{~cm} / \mathrm{s}$ in human and $3.3 \pm 0.4 \times 10^{-5} \mathrm{~cm} / \mathrm{s}$ in rodents (Sands, 2002). To maintain the cell osmotic stability, urea must transverse erythrocyte membranes rapidly (Macey and Yousef, 1988; Fenton et al., 2005) when erythrocytes pass through vasa recta from the cortex to IM. The high efficiency of UT-B expressed in erythrocytes prevents the cells from shrinking in the IM where urea concentration accumulation is 50- to 200fold higher than that in peripheral blood (Sands, 2002), and subsequently swelling after the cells leave the hyperosmotic environment. However, the role of UT-B in erythrocyte survival is currently speculative. Theoretical calculations and in vivo studies show that only about $0.5 \%$ of the total cardiac output of erythrocytes pass through the vasa recta (Lieberthal et al., 1987). Moreover, erythrocyte survival is not affected by either increased or decreased urine concentrating ability (Liu et al., 2011).

Urea transporter-B in erythrocytes also plays an important role in the urine concentrating mechanism. Lieberthal et al.'s (1987) study shows that urine cannot be well concentrated in the isolated kidney perfused without erythrocytes. The concentrating ability is restored after adding erythrocytes to the perfusate. The presence of UT-B enables rapid urea intake and release into and out of erythrocytes in the IM as they circulate away from the IM. This process helps build the urea concentration gradient. In addition, the countercurrent exchange between AVR and DVR, which conserves urea in the kidney, also depends on rapid urea transport through erythrocytes.
Urea transporter-B transports a number of urea analogs, such as formamide, acetamide, thiourea, and methylurea, with various rates (Figure 4; Zhao et al., 2007). By competing with high affinity to UT-B, urea analogs decrease UT-B urea permeability and result in UT-B blockage (Goodman, 2002). Thiourea, one of the analogs of urea, was shown to have a 10 -fold greater binding affinity to UT-B than urea (Zhao et al., 2007). Of note, erythrocytes have high water permeability mainly mediated by water channel AQP1 (Yang et al., 2001). UT-B is also permeable to water (Figure 5A; Yang and Verkman, 1998). The low water permeability found in AQP1/UT-B double knockout erythrocytes was also seen after $\mathrm{HgCl}_{2}$ treatment of UT-B null erythrocytes or phloretin treatment of AQP1 null erythrocytes (Figure 5B; Yang and Verkman, 2002). The single channel water permeability of UT-B is $7.5 \times 10^{-14} \mathrm{~cm}^{3} / \mathrm{s}$, similar to that of AQP1 (Yang et al., 2001), which provides direct functional evidence for UT-B-facilitated water transport in erythrocytes and suggests that urea traverses an aqueous pore in the UT-B protein (Figure 5C; Yang and Verkman, 1998).

\section{HEART}

Three different sizes of UT-A proteins, 39,51 , and $56 \mathrm{kDa}$ in rats and 51,56 , and $97 \mathrm{kDa}$ in human, are found in heart when blotting the heart tissue with UT-A1 antibody (Duchesne et al., 2001). However, the type of UT-A isoforms is still undetermined. The 56-kDa protein is up-regulated in the uremia and hypertensive rat models. In human, both of 56 and $51 \mathrm{kDa}$ protein expression are increased in heart failure caused by dilated cardiomyopathy.
A

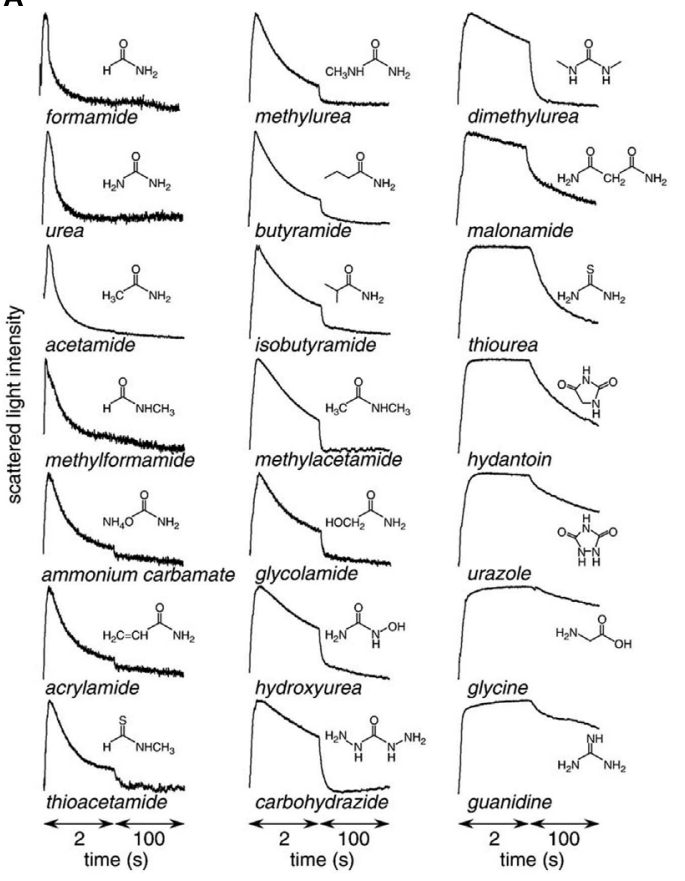

B

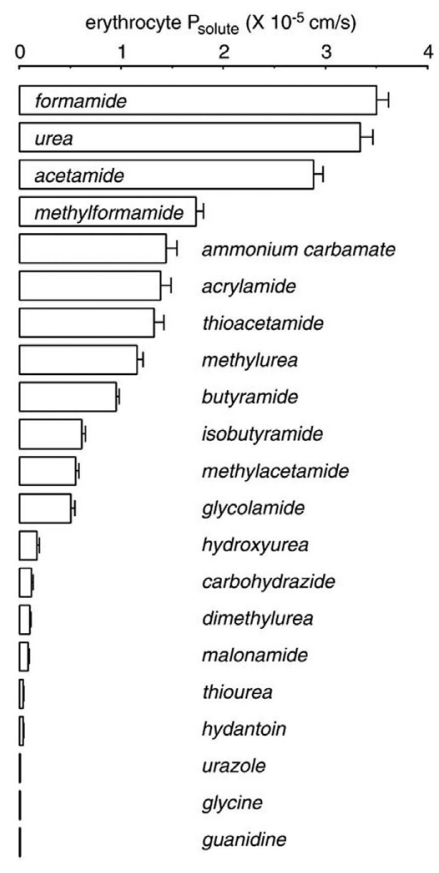

FIGURE 4 | Urea analog permeability mediated by UT-B. Erythrocyte solute permeability measured by stopped-flow light scattering. (A) Representative curves for the time course of scattered light intensity at $10^{\circ} \mathrm{C}$ in response to a 250-mM inwardly directed gradient of urea. (B) Averaged solute permeability coefficients (Ps) for experiments done as in panel A (mean \pm S.E., $n=3$ ). Reproduced from Zhao et al. (2007). 

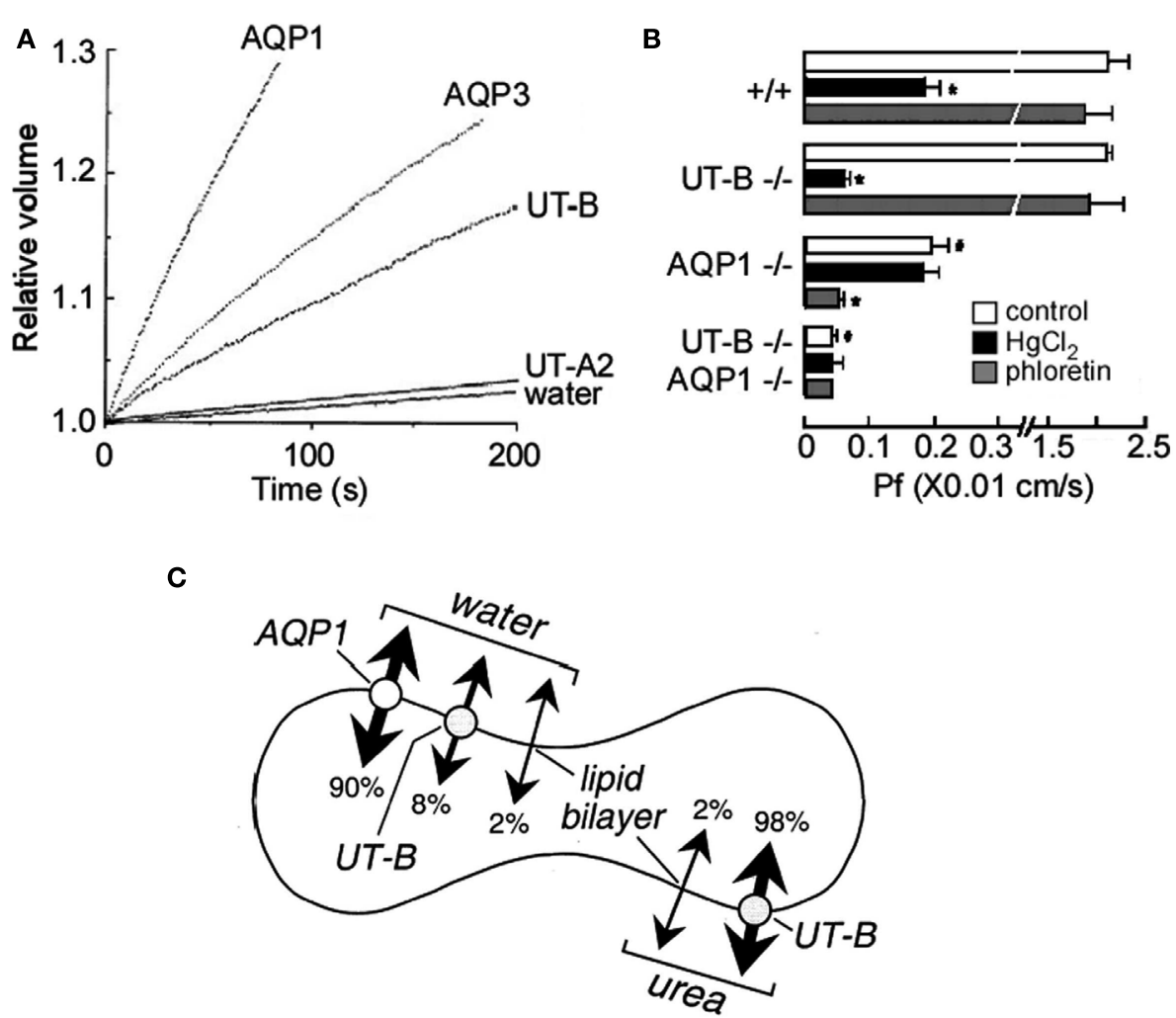

FIGURE 5 | Water and urea permeability mediated by aquaporins and urea transporters. (A). Water and urea permeability in oocytes expressing aquaporins and urea transporters. Time course of oocyte swelling was measured at $10^{\circ} \mathrm{C}$ in response to a fivefold dilution of extracellular Barth's buffer with distilled water. Oocytes were injected with $50 \mathrm{~nL}$ of water (as control) or cRNAs (5 ng) encoding AQP1, AQP3, UT-A2, or UT-B. (B) Erythrocyte water permeability $\left(P_{f}\right)$ measured by stop-flow light scattering based on the time course of changes in erythrocyte volume in response to a
250-mM inwardly directed sucrose gradient. These data were obtained in erythrocytes from mice of indicated genotype at $10^{\circ} \mathrm{C}$, under control conditions and in the presence of $0.3 \mathrm{mM} \mathrm{HgCl}_{2}$ or $0.7 \mathrm{mM}$ phloretin. Values are expressed as means $\pm \mathrm{SE}, n=3$ mice/genotype. ${ }^{*} p<0.01$ compared with no inhibitor. ${ }^{*} p<0.01$ compared with WT in control conditions $P_{\mathrm{f}}$. (C) Relative contributions of AQP1, UT-B, and the lipid bilayer to erythrocyte water and urea permeability at $10^{\circ} \mathrm{C}$. Reproduced from Yang and Verkman (1998, 2002).
Urea transporter-B is highly expressed in hearts. ECG recording shows that the UT-B knockout mouse has a prolonged P-R interval from early ( 6 week) to old ages ( 52 weeks), indicating that the conduction from atrium cordis to cardiac ventricle is delayed (Figures 6A,B). However, UT-B deletion results in increased type II and III atrial ventricular heart block attack only in the aged mice ( $>52$ weeks). The significantly reduced APA and $V_{\max }$ demonstrate that the cardiocyte excitability and conductibility are impaired in UT-B null mice (Yu et al., 2009). The accumulated urea in cells might be involved in the progressive heart block in UT-B null mice (Meng et al., 2009). However, the causative role of urea accumulation in cardiac disease is still in debate (Scheuer and Stezoski, 1973). One in vitro study shows that urea at 3-300 mM had a protective effect to heart damage induced by ischemia and electrolysis (Wang et al., 1999). Other possible mechanisms may exist. Interestingly, TNNT2 (Troponin T Type 2) is significantly increased in UT-B null hearts (Hershberger et al., 2009). TNNT2 is an important factor in heart that acts as a $\mathrm{Ca}^{2+}$ sensor (Yu et al., 2009) and affects the contractility of myocardium (Sehnert et al., 2002). The increased TNNT2 might be involved in the development of heart block in UT-B null mice. Atrial natriuretic peptide
(ANF) is increased in aged UT-B knockout mice ( $>52$ weeks; Figure 6C; Meng et al., 2009). ANP is regarded as a hypertrophy protective factor (Oliver et al., 1997; Horio et al., 2000) and hypertrophy is related to the heart block (Moak et al., 2001).

\section{BRAIN}

Urea transporter-B is expressed in brain, mainly in astrocytes and ependymal cells. Brain contains a high concentration of urea, the same as seen in liver (Buniatian and Davtian, 1966). Intriguingly, UT-B is not detected in endothelial cells of blood vessels which form the blood-brain barrier (BBB). Indeed, the permeability of urea across $\mathrm{BBB}$ is relatively slow and reversible (Kleeman et al., 1962). Urea mediated by UT-B enters into the astrocytes, passes through the ependymal cells, and finally gets into the cerebrospinal fluid (CSF) to be excreted (Couriaud et al., 1996). In support of this, arginase II, the key enzyme for urea synthesis in brain, was detected to have a larger distribution than UT-B (Braissant et al., 1999).

In 5/6 nephrectomized uremic rat models, both UT-B mRNA and protein in brain was significantly reduced ( $\mathrm{Hu}$ et al., 2000). In contrast, AQP4 and AQP9 were remarkably increased 
A
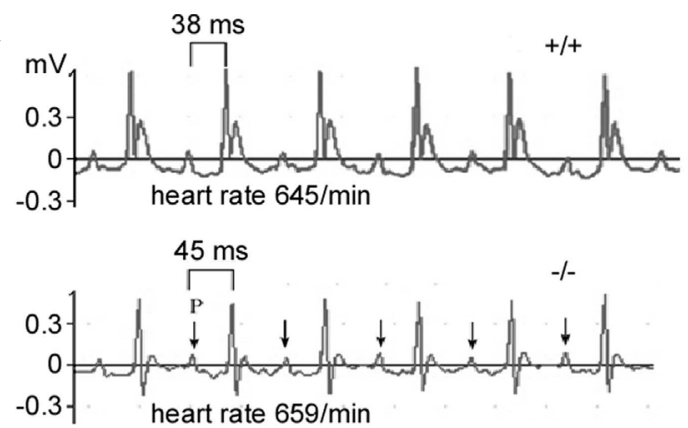

B
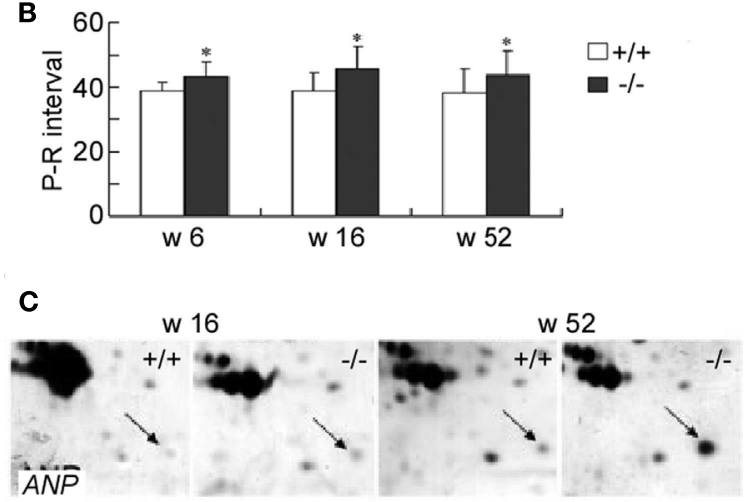

FIGURE 6 | Surface electrocardiogram and action potential in mice lacking UT-B. (A) The II standard lead ECG of WT and UT-B null mice. (B) The P-R interval in WT and UT-B null mice (mean $+\mathrm{SD}, n=20,{ }^{*} p<0.05$ vs. WT mice). (C) The expression level of ANP in 16- and 52-week-old WT and UT-B null mice. Reproduced from Meng et al. (2009), Yu et al. (2009).

(Trinh-Trang-Tan et al., 2005). This might be the reason for the rapid development of brain edema in dialysis. The reduced UT-B in astrocytes impairs urea effusion and results in urea accumulation in brain. Subsequently, the elevated osmolarity drives water to flow into the brain through the water channels AQP4 and AQP9.

Urea transporter-B is expressed in brain (Figure 7A) and controls urea concentration in brain tissue (Figure 7B; Guo et al., 2007). UT-B may also play an important role in the regulation of nitric oxide (NO) production in brain. Urea has an inhibitive effect on $\mathrm{L}$-arginine transport into the epithelial cells (Xiao et al., 2001) and phloretin can block this inhibition (Wagner et al., 2002). UT-B likely mediates urea transport and regulates intracellular L-arginine concentration. UT-B null mice present both depression-like behavior (Li et al., 2012) with an extended immobility time in forced swim test (Figure 7C) and less interest in sucrose in a sucrose preference test (Figure 7D). Decreased rCBF (cerebral blood flow) supports the hypothesis of "vascular depression" (Figure 7E). Histologically, swelling of unmyelinated fibers was observed in hippocampus. This change may reflect the degeneration of membrane structures and impaired axoplasmic transport which contribute to the depressed-like behavior (Figure 7F). Notably, the UT-B null mouse has decreased NO production in brain and increased urea concentration especially in hippocampus in both acute urea load tests and normal condition (Figure 7B). Acute urea load decreases nNOS expression (Li et al., 2012).

\section{TESTIS}

Urea transporter-A5 is reported in testis. However, Northern blot analysis revealed different UT-A mRNA transcripts at 4.0, 3.3, 2.8, and $1.7 \mathrm{~kb}$ in testis (Tsukaguchi et al., 1997), which are all longer than UT-A5. This suggests that other types of UT-A isoforms may also exist. UT-A proteins were found in the nuclei of Sertoli cells throughout development of the seminiferous tubules (SMT) as well as in the residual bodies at stage VIII of SMT (Fenton et al., 2002a). Considering that the Sertoli cell nuclei do not produce urea, the function of UT-A in the nuclei is unclear and may not be related to urea transport. The residual bodies are involved in the formation of the spermatozoa head while spermatids transform into spermatozoa. This process requires a reduction of cell volume. UT-A in residual bodies probably participates in reducing cell volume by rapidly excreting urea, while water channel AQP7 and AQP8 excrete fluid. In support of this, UT-A1 and UT-A3 double knockout mice have enlarged testis (Fenton et al., 2005). Interestingly, UT-A5 protein increases at day 20 after birth, the same time when SMT begins to produce fluid to drive sperm to reproductive tracts.

Urea transporter-B mRNA also expresses in Sertoli cells and increases on stage II-III of SMT development. In vitro study shows phloretin-inhibited urea diffusion across Sertoli cells and SMT cell membranes following the concentration gradient of urea (Guo et al., 2007). In UT-B knockout mice, urea was significantly accumulated in the testis (Figure 8A). After 5 min of injection, $\left[{ }^{14} \mathrm{C}\right]$ urea accumulation in testis was significantly less in UT-B null mice compared to the wild-type mice (Figure 8B). This suggests that urea transport across SMT epithelia and exit from Sertoli cells is decreased in the absence of UT-B (Guo et al., 2007). UT-B null mouse has a larger testis and earlier breeding time (Figures $8 C, D$ ).

\section{URINARY TRACT}

Urea transporter-B is identified in urinary tract epithelial cells both in the cell membrane and some cytoplasmic vesicles (Lucien et al., 2005). Diets with different contents of protein or sodium do not affect the expression of UT-B in bladder and ureter. However, hydropenia causes a significant increase of UT-B expression in ureter, but not bladder. Considering that bladder and ureter have higher urea and creatinine concentration than those in plasma, the reabsorption of urea and creatinine from luminal urine to urinary tissue may exist (Spector et al., 2007). The high concentration of urea may diffuse to the epithelial cells where the urea is then transported across the basolateral membrane to the muscular layer and enter into the capillaries by UT-B UT. In terms of this, UT-B may be involved in the regulation of epithelial cell volume and osmolality (Lucien et al., 2005). Both UT-A mRNA and protein are found in rat bladders (Doran et al., 2006), suggesting that UT-A might participate in the transportation of urea from urine to the apical membranes of epithelial cells.

Interestingly, new studies reported that UT-B might be associated with urinary bladder cancer (UBC; Garcia-Closas et al., 2011; Rafnar et al., 2011). A novel UBC susceptibility locus is found on chromosome 18q12.3 where SLC14A1 localizes (Garcia-Closas et al., 2011; Rafnar et al., 2011). Urine volume and frequency of urination, which is partly regulated by UT-B, may affect the risk of UBC occurrence. 


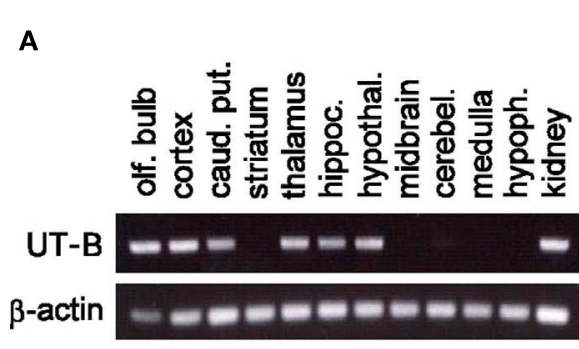

C

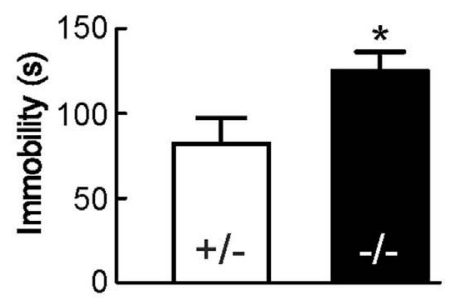

E

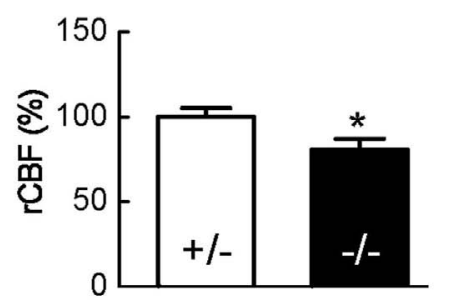

FIGURE 7 | Mice lacking UT-B display depression-like behavior. (A) UT-B mRNA expression in indicated brain regions determined by RT-PCR. $\alpha$-actin was used as reference control. (B) Urea concentrations in Olf, olfactory bulb; Cor, cortex; Hip, hippocampus; Hypo, hypothalamus. Mean $\pm \mathrm{SE},{ }^{*} p<0.05$, ${ }^{*} p<0.01$, ${ }^{* *} p<0.001$, compared with heterozygous mice, $n=10$. (C) Forced swim test.

\section{LIVER}

Liver is the major organ for urea synthesis. There are two different sizes of UT-A protein identified in liver and isolated hepatocytes from rats, mice, and chimpanzees (Klein et al., 1999). In uremic rats, the $49-\mathrm{kDa}$ UT-A protein mainly expressed in the cell membrane was significantly increased, while the $36-\mathrm{kDa}$ cytosolic UT-A protein did not show any change (Klein et al., 1999). UT-B is also reported to be expressed in liver (Sands, 2000). How the UT mediates urea transport in liver is not clear.

\section{INTESTINE}

Urea transporter-B is expressed at the apical membrane of superficial epithelial cells and crypts in colon and small intestine. However, the expression of UT-A in intestine is still controversial (Inoue et al., 2005). Colon is believed to be permeable to urea (Moran and Jackson, 1990). Intraluminal urea infiltrated from blood is partly decomposed by intestinal flora into ammonia and carbon dioxide. Ammonia is then reabsorbed back into blood to participate in further metabolic reactions, which accomplishes nitrogen reutilization (Spector et al., 2004). Intestinal UT-B protein abundance is increased in rats when fed a low-protein diet or a $20 \%$ urea diet, but there is no change in UT-B abundance in animals fed a highprotein diet or in rats with uremia (Inoue et al., 2005). Intestinal

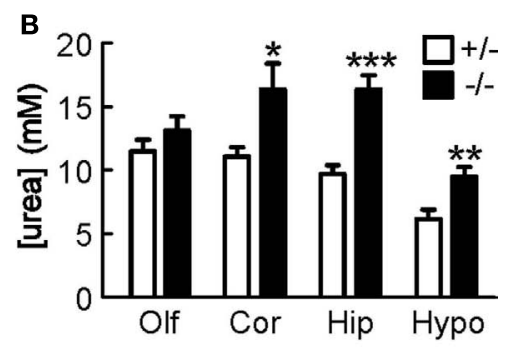

D

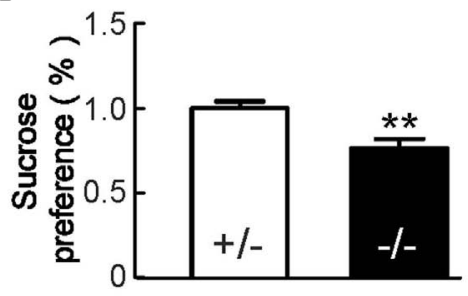

$\mathbf{F}$

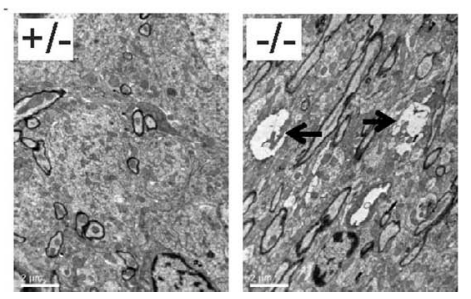

Immobility time was recorded for $5 \mathrm{~min}$. (D) Sucrose preference test. Mean \pm SE, $n=15$. (E) rCBF was assessed by laser Doppler flowmetry. Mean $\pm S E, n=10$. (F) Representative transmission electron microscopic images of the hippocampus, which show swelling of unmyelinated fibers with myelin figure in UT-B null mice. Reproduced from Li et al. (2012).
UT-B mediates the urea movement across intestinal epithelial cells according to transepithelial urea flux assays in vitro (Spector et al., 2004).

\section{PHARMACOLOGICAL PROSPECT UT-B INHIBITOR}

Urea plays an important role in the urinary concentration mechanism. Development of a UT inhibitor may have clinical significance in treating water overloaded diseases. Phloretin is a commonly used UT-B inhibitor experimentally, but its broad inhibitory activity, including inhibition transport of glucose (Lefevre and Marshall, 1959) and glycerol (vom Dahl and Haussinger, 1997), impedes its usage as a UT-B inhibitor. Urea analogs, such as methylurea, thiourea, and dimethylurea, competitively inhibit UT-B urea transport, usually at high concentrations (Zhao et al., 2007). The Verkman group has published some potentially promising reagents (Levin et al., 2007). By high-throughput screening, they identified some UT-B inhibitors and successfully established an erythrocyte osmotic lysis assay to evaluate these compounds. Human RBCs were preloaded with urea or urea analogs (acetamide), then the cells were changed to an isosmotic solution without urea. Under normal conditions, urea exits the cells through UT-B. However, in the presence of UT-B inhibitors, 


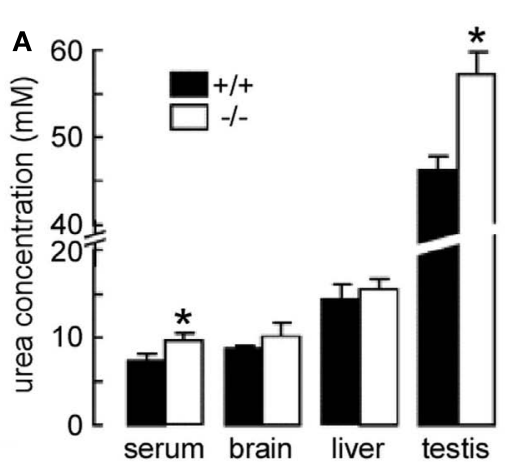

C

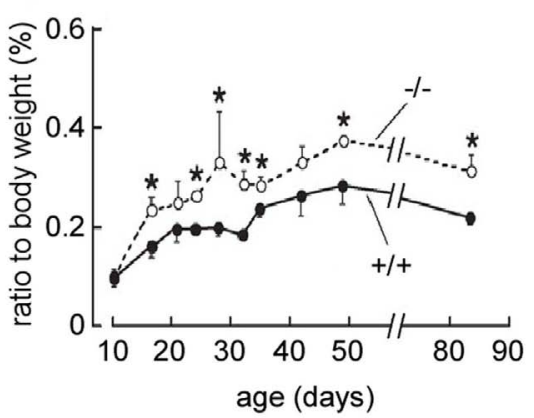

FIGURE 8 | Early maturation in the male reproductive system in UT-B null mice. (A) Urea concentration in plasma and homogenized tissues. Tissues from 84-day-old mice were homogenized in water. Urea concentrations in supernatants of centrifuged homogenates were measured. (B) Kinetics of $\left[{ }^{14} \mathrm{C}\right]$ urea uptake and organ morphology in wild-type vs. UT-B null mice. After renal blood flow was blocked, a bolus of $\left[{ }^{14} \mathrm{C}\right]$ urea was injected intravenously, and the blood, brain, liver, spleen, and testis were sampled at $5 \mathrm{~min} .\left[{ }^{14} \mathrm{C}\right]$ urea accumulation in different tissues was normalized to serum. Values are

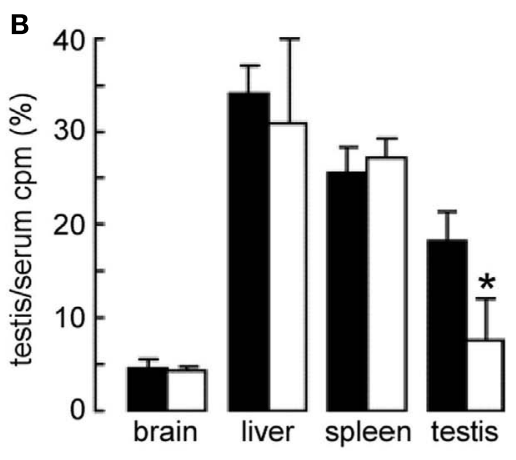

D

parents

competing mating test

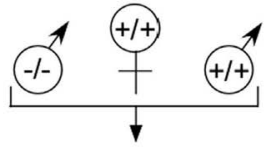

mating age of males $48 \pm 3$

number of litter

size of litter

number of pups

genotype of pups

gender of pups
7

$7 \pm 2$

$48+1-$

$23 \mathrm{M} 25 \mathrm{~F}$

expressed as means \pm SE ( $n=4$ mice). ${ }^{*} p<0.01$ vs. WT mice. (C) Age-related changes in testis weights. The left testis were isolated and weighed. The $x$-axis shows the age of the mice, and the $y$-axis shows the testis percentage of body weight $\left(n=6,{ }^{*} p<0.05\right)$. (D) Breeding performance of maturing male mice. Male (M) mice at 35 days of age were housed with 10-week-old WT female (F) mice. Data are shown as means \pm SE for seven pairs of competing mates (left) and seven pairs of WT controls (right). Reproduced from Guo et al. (2007).

urea accumulates in the cells. Water enters the cells through AQP1 resulting in swelling and cell lysis. This could be measured by nearinfrared light scattering. Of note, UT-B not only transports urea, but also water in RBC (Figure 5), but in vitro tests show that UT-B only participates in $8 \%$ of the total transport of water, while $90 \%$ of water is transported by AQP1. The decrease in water permeability resulting from the inhibition of UT-B did not significantly affect this erythrocyte osmotic model. After optimizing chemically modified compounds, Verkman et al. reported two inhibitors blocking UT-B but not UT-A or AQP activity. Considering the crucial role of UT-B in urine concentration, this discovery may lead to the

\section{REFERENCES}

Bagnasco, S. M. (2003). Gene structure of urea transporters. Am. J. Physiol. Renal Physiol. 284, F3-F10.

Bankir, L., Chen, K., and Yang, B. (2004). Lack of UT-B in vasa recta and red blood cells prevents urea-induced improvement of urinary concentrating ability. Am. J. Physiol. Renal Physiol. 286, F144-F151.

Berger, U. V., Tsukaguchi, H., and Hediger, M. A. (1998). Distribution of mRNA for the facilitated urea transporter UT3 in the rat nervous system. Anat. Embryol. 197, 405-414. Braissant, O., Gotoh, T., Loup, M., Mori, M., and Bachmann, C. (1999). Larginine uptake, the citrulline-NO cycle and arginase II in the rat brain: an in situ hybridization study. Brain Res. Mol. Brain Res. 70, 231-241.

Buniatian, H. C., and Davtian, M. A. (1966). Urea synthesis in brain. J. Neurochem. 13, 743-753.

Cai, Q., Nelson, S. K., McReynolds, M. R., Diamond-Stanic, M. K.,

development of a new type of diuretic capable of inhibiting urea absorption without changing other solutes.

\section{ACKNOWLEDGMENTS}

We greatly thank Drs. Jeff Sands and Janet Klein for critical reading of this manuscript. This work was supported by Chinese National Natural Science Foundation grants 30870921 and 81170632 (to B. Yang), Drug Discovery Program grant 2009ZX09301-010-30 (to B. Yang), The Research Fund for the Doctoral Program of Higher Education 20100001110047 (to B. Yang), and by NIH R01-DK087838 (to G. Chen).

Elliott, D., and Brooks, H. L. (2010). Vasopressin increases expression of UT-A1, UT-A3, and ER chaperone GRP78 in the renal medulla of mice with a urinary concentrating defect. Am. J. Physiol. Renal Physiol. 299, F712-F719.

Chou, C. L., and Knepper, M. A. (1989). Inhibition of urea transport in inner medullary collecting duct by phloretin and urea analogues. Am. J. Physiol. 257, F359-F365.
Couriaud, C., Ripoche, P., and Rousselet, G. (1996). Cloning and functional characterization of a rat urea transporter: expression in the brain. Biochim. Biophys. Acta 1309, 197-199.

Doran, J. J., Klein, J. D., Kim, Y. H., Smith, T. D., Kozlowski, S. D., Gunn, R. B., and Sands, J. M. (2006). Tissue distribution of UT-A and UT-B mRNA and protein in rat. Am. J. Physiol. Regul. Integr. Comp. Physiol. 290, R1446-R1459. 
Duchesne, R., Klein, J. D., Velotta, J. B., Doran, J. J., Rouillard, P., Roberts, B. R., McDonough, A. A., and Sands, J. M. (2001). UT-A urea transporter protein in heart: increased abundance during uremia, hypertension, and heart failure. Circ. Res. 89, 139-145.

Fenton, R. A. (2008). Urea transporters and renal function: lessons from knockout mice. Curr. Opin. Nephrol. Hypertens. 17, 513-518.

Fenton, R. A., Chou, C. L., Stewart, G. S., Smith, C. P., and Knepper, M. A. (2004). Urinary concentrating defect in mice with selective deletion of phloretin-sensitive urea transporters in the renal collecting duct. Proc. Natl. Acad. Sci. U.S.A. 101, 7469-7474.

Fenton, R. A., Cottingham, C. A., Stewart, G. S., Howorth, A., Hewitt, J. A., and Smith, C. P. (2002a). Coordinated expression of UT-A and UT-B urea transporters in rat testis. Am. J. Physiol. Cell Physiol. 282, C1492C1501.

Fenton, R. A., Stewart, G. S., Carpenter, B., Howorth, A., Potter, E. A., Cooper, G. J., and Smith, C. P. (2002b). Characterization of mouse urea transporters UT-A1 and UTA2. Am. J. Physiol. Renal Physiol.283, F817-F825.

Fenton, R. A., Flynn, A., Shodeinde, A., Smith, C. P., Schnermann, J., and Knepper, M. A. (2005). Renal phenotype of UT-A urea transporter knockout mice. J. Am. Soc. Nephrol. 16, 1583-1592.

Fenton, R. A., Hewitt, J. E., Howorth, A., Cottingham, C. A., and Smith, C. P. (1999). The murine urea transporter genes Slc14al and Slc14a2 occur in tandem on chromosome 18. Cytogenet. Cell Genet. 87, 95-96.

Fenton, R. A., Howorth, A., Cooper, G. J., Meccariello, R., Morris, I. D., and Smith, C. P. (2000). Molecular characterization of a novel UT-A urea transporter isoform (UT-A5) in testis. Am. J. Physiol. Cell Physiol. 279, C1425-C1431.

Fenton, R. A., and Knepper, M. A. (2007). Urea and renal function in the 21st century: insights from knockout mice. J. Am. Soc. Nephrol. $18,679-688$.

Frohlich, O., Aggarwal, D., Klein, J. D., Kent, K. J., Yang, Y., Gunn, R. B., and Sands, J. M. (2008). Stimulation of UT-A1-mediated transepithelial urea flux in MDCK cells by lithium. Am. J. Physiol. Renal Physiol. 294, F518-F524.
Frohlich, O., Klein, J. D., Smith, P. M., Sands, J. M., and Gunn, R. B. (2006). Regulation of UT-A1-mediated transepithelial urea flux in MDCK cells. Am. J. Physiol. Cell Physiol. 291, C600-C606.

Gallucci, E., Micelli, S., and Lippe, C. (1971). Non-electrolyte permeability across thin lipid membranes. Arch. Int. Physiol. Biochim. 79, 881-887.

Gamble, J. L., McKhann, C. M., Butler, A. M., and Tuthill, E. (1934). An economy of water in renal function referable to urea. Am. J. Physiol. 109, 139-154.

Garcia-Closas, M., Ye, Y., Rothman, N., Figueroa, J. D., Malats, N., Dinney, C. P., Chatterjee, N., ProkuninaOlsson, L., Wang, Z., Lin, J., Real, F. X., Jacobs, K. B., Baris, D., Thun, M., De Vivo, I., Albanes, D., Purdue, M. P., Kogevinas, M., Kamat, A. M., Lerner, S. P., Grossman, H. B., Gu, J., Pu, X., Hutchinson, A., Fu, Y. P., Burdett, L., Yeager, M., Tang, W., Tardon, A., Serra, C., Carrato, A., Garcia-Closas, R., Lloreta, J., Johnson, A., Schwenn, M., Karagas, M. R., Schned, A., Andriole, G. Jr., Grubb, R. III, Black, A., Jacobs, E. J., Diver, W. R., Gapstur, S. M., Weinstein, S. J., Virtamo, J., Hunter, D. J., Caporaso, N., Landi, M. T., Fraumeni, J. F. Jr., Silverman, D. T., Chanock, S. J., and Wu, X. (2011). A genome-wide association study of bladder cancer identifies a new susceptibility locus within SLC14A1, a urea transporter gene on chromosome 18q12.3. Hum. Mol. Genet. 20, 4282-4289.

Goodman, B. E. (2002). Transport of small molecules across cell membranes: water channels and urea transporters. Adv. Physiol. Educ. 26, 146-157.

Guo, L., Zhao, D., Song, Y., Meng, Y., Zhao, H., Zhao, X., and Yang, B. (2007). Reduced urea flux across the blood-testis barrier and early maturation in the male reproductive system in UT-B-null mice. Am. J. Physiol. Cell Physiol. 293, C305-C312.

Hershberger, R. E., Pinto, J. R., Parks, S. B., Kushner, J. D., Li, D., Ludwigsen, S., Cowan, J., Morales, A., Parvatiyar, M. S., and Potter, J. D. (2009). Clinical and functional characterization of TNNT2 mutations identified in patients with dilated cardiomyopathy. Circ. Cardiovasc. Genet. 2, 306-313.

Horio, T., Nishikimi, T., Yoshihara, F., Matsuo, H., Takishita, S., and Kangawa, K. (2000). Inhibitory regulation of hypertrophy by endogenous atrial natriuretic peptide in cultured cardiac myocytes. Hypertension 35 19-24.

Hu, M. C., Bankir, L., Michelet, S., Rousselet, G., and Trinh-Trang-Tan, M. M. (2000). Massive reduction of urea transporters in remnant kidney and brain of uremic rats. Kidney Int. 58, 1202-1210.

Inoue, H., Jackson, S. D., Vikulina, T., Klein, J. D., Tomita, K., and Bagnasco, S. M. (2004). Identification and characterization of a Kidd antigen/UT-B urea transporter expressed in human colon. Am. J. Physiol. Cell Physiol. 287, C30-C35.

Inoue, H., Kozlowski, S. D., Klein, J. D., Bailey, J. L., Sands, J. M., and Bagnasco, S. M. (2005). Regulated expression of renal and intestinal UT-B urea transporter in response to varying urea load. Am. J. Physiol. Renal Physiol. 289, F451-F458.

Karakashian, A., Timmer, R. T., Klein, J. D., Gunn, R. B., Sands, J. M., and Bagnasco, S. M. (1999). Cloning and characterization of two new isoforms of the rat kidney urea transporter: UT-A3 and UT-A4. J. Am Soc. Nephrol. 10, 230-237.

Kato, A., Klein, J. D., Zhang, C., and Sands, J. M. (2000). Angiotensin II increases vasopressin-stimulated facilitated urea permeability in rat terminal IMCDs. Am J. Physiol. Renal Physiol. 279, F835-F840

Kim, Y. H., Kim, D. U., Han, K. H., Jung, J. Y., Sands, J. M., Knepper, M. A., Madsen, K. M., and Kim, J. (2002). Expression of urea transporters in the developing rat kidney. Am. J. Physiol. Renal Physiol. 282, F530-F540.

Kleeman, C. R., Davson, H., and Levin, E. (1962). Urea transport in the central nervous system. Am. J. Physiol. 203, 739-747.

Klein, J. D., Martin, C. F., Kent, K. J., and Sands, J. M. (2012). Protein kinase C alpha mediates hypertonicitystimulated increase in urea transporter phosphorylation in the inner medullary collecting duct. Am. J. Physiol. Renal Physiol. 302, F1098F1103.

Klein, J. D., Sands, J. M., Qian, L., Wang, X., and Yang, B. (2004). Upregulation of urea transporter UT$\mathrm{A} 2$ and water channels AQP2 and $\mathrm{AQP} 3$ in mice lacking urea transporter UT-B. J. Am. Soc. Nephrol. 15, 1161-1167

Klein, J. D., Timmer, R. T., Rouillard, P., Bailey, J. L., and Sands, J.
M. (1999). UT-A urea transporter protein expressed in liver: upregulation by uremia. J. Am. Soc. Nephrol. 10, 2076-2083.

Lefevre, P. G., and Marshall, J. K. (1959). The attachment of phloretin and analogues to human erythrocytes in connection with inhibition of sugar transport. J. Biol. Chem. 234, 3022-3026.

Lei, T., Zhou, L., Layton, A. T., Zhou, H., Zhao, X., Bankir, L., and Yang, B. (2011). Role of thin descending limb urea transport in renal urea handling and the urine concentrating mechanism. Am. J. Physiol. Renal Physiol. 301, F1251-F1259.

Levin, E. J., Quick, M., and Zhou, M. (2009). Crystal structure of a bacterial homologue of the kidney urea transporter. Nature 462, 757-761.

Levin, M. H., de la Fuente, R., and Verkman, A. S. (2007). Urearetics: a small molecule screen yields nanomolar potency inhibitors of urea transporter UT-B. FASEB J. 21, 551-563.

Li, X., Ran, J., Zhou, H., Lei, T., Zhou, L., Han, J., and Yang, B. (2012). Mice lacking urea transporter UT-B display depressionlike behavior. J. Mol. Neurosci. 46, 362-372.

Lieberthal, W., Stephens, G. W., Wolf, E. F., Rennke, H. G., Vasilevsky, M. L., Valeri, C. R., and Levinsky, N. G. (1987). Effect of erythrocytes on the function and morphology of the isolated perfused rat kidney. Ren. Physiol. 10, 14-24.

Liu, L., Lei, T., Bankir, L., Zhao, D., Gai, X., Zhao, X., and Yang, B. (2011). Erythrocyte permeability to urea and water: comparative study in rodents, ruminants, carnivores, humans, and birds. J. Comp. Physiol. B Biochem. Syst. Environ. Physiol. 181, 65-72.

Lucien, N., Bruneval, P., Lasbennes, F., Belair, M. F., Mandet, C., Cartron, J. P., Bailly, P., and Trinh-TrangTan, M. M. (2005). UT-B1 urea transporter is expressed along the urinary and gastrointestinal tracts of the mouse. Am. J. Physiol. Regul. Integr. Comp. Physiol. 288, R1046-R1056.

Macey, R. I., and Yousef, L. W. (1988). Osmotic stability of red cells in renal circulation requires rapid urea transport. Am. J. Physiol. 254, C669-C674.

Meng, Y., Zhao, C., Zhang, X., Zhao, H., Guo, L., Lu, B., Zhao, X., and Yang, B. (2009). Surface electrocardiogram 
and action potential in mice lacking urea transporter UTB. Sci. China C Life Sci. 52, 474-478.

Moak, J. P., Barron, K. S., Hougen, T. J., Wiles, H. B., Balaji, S., Sreeram, N., Cohen, M. H., Nordenberg, A., Van Hare, G. F., Friedman, R. A., Perez, M., Cecchin, F., Schneider, D. S., Nehgme, R. A., and Buyon, J. P. (2001). Congenital heart block: development of late-onset cardiomyopathy, a previously underappreciated sequela. J. Am. Coll. Cardiol. 37, 238-242.

Moran, B. J., and Jackson, A. A. (1990). 15N-urea metabolism in the functioning human colon: luminal hydrolysis and mucosal permeability. Gut 31, 454-457.

Oliver, P. M., Fox, J. E., Kim, R., Rockman, H. A., Kim, H. S., Reddick, R. L., Pandey, K. N., Milgram, S. L., Smithies, O., and Maeda, N. (1997). Hypertension, cardiac hypertrophy, and sudden death in mice lacking natriuretic peptide receptor A. Proc. Natl. Acad. Sci. U.S.A. 94, 14730-14735.

Olives, B., Mattei, M. G., Huet, M., Neau, P., Martial, S., Cartron, J. P., and Bailly, P. (1995). Kidd blood group and urea transport function of human erythrocytes are carried by the same protein. J. Biol. Chem. 270, 15607-15610.

Olives, B., Neau, P., Bailly, P., Hediger, M. A., Rousselet, G., Cartron, J. P., and Ripoche, P. (1994). Cloning and functional expression of a urea transporter from human bone marrow cells. J. Biol. Chem. 269, 31649-31652.

Pallone, T. L. (1994). Characterization of the urea transporter in outer medullary descending vasa recta. Am. J. Physiol. 267, R260-R267.

Potter, E. A., Stewart, G., and Smith, C. P. (2006). Urea flux across MDCKmUT-A2 monolayers is acutely sensitive to AVP, cAMP, and $[\mathrm{Ca} 2+] \mathrm{i}$. Am. J. Physiol. Renal Physiol. 291, F122-F128.

Rafnar, T., Vermeulen, S. H., Sulem, P., Thorleifsson, G., Aben, K. K., Witjes, J. A., Grotenhuis, A. J., Verhaegh, G. W., Hulsbergen-van de Kaa, C. A., Besenbacher, S., Gudbjartsson, D., Stacey, S. N., Gudmundsson, J., Johannsdottir, H., Bjarnason, H., Zanon, C., Helgadottir, H., Jonasson, J. G., Tryggvadottir, L., Jonsson, E., Geirsson, G., Nikulasson, S., Petursdottir, V. T., Bishop, D., Chung-Sak, S., Choudhury, A., Elliott, F., Barrett,
J. H., Knowles, M. A., de Verdier, P. J., Ryk, C., Lindblom, A., Rudnai, P., Gurzau, E., Koppova, K., Vineis, P., Polidoro, S., Guarrera, S., Sacerdote, C., Panadero, A., Sanz-Velez, J. I., Sanchez, M., Valdivia, G., Garcia-Prats, M. D., Hengstler, J. G., Selinski, S., Gerullis, H., Ovsiannikov, D., Khezri, A., Aminsharifi, A., Malekzadeh, M., van den Berg, L. H., Ophoff, R. A., Veldink, J. H., Zeegers, M. P., Kellen, E., Fostinelli, J., Andreoli, D., Arici, C., Porru, S., Buntinx, F., Ghaderi, A., Golka, K., Mayordomo, J. I., Matullo, G., Kumar, R., Steineck, G., Kiltie, A. E., Kong, A., Thorsteinsdottir, U., Stefansson, K., and Kiemeney, L. A. (2011). European genome-wide association study identifies SLC14A1 as a new urinary bladder cancer susceptibility gene. Hum. Mol. Genet. 20, 4268-4281.

Sands, J. M. (2000). Regulation of urea transporter proteins in kidney and liver. Mt. Sinai J. Med. 67, 112-119.

Sands, J. M. (2002). Molecular approaches to urea transporters. J. Am. Soc. Nephrol. 13, 2795-2806.

Sands, J. M., and Knepper, M. A. (1987). Urea permeability of mammalian inner medullary collecting duct system and papillary surface epithelium. J. Clin. Invest. 79, 138-147.

Scheuer, J., and Stezoski, W. (1973). The effects of uremic compounds on cardiac function and metabolism. J. Mol. Cell. Cardiol. 5, 287-300.

Sehnert, A. J., Huq, A., Weinstein, B. M., Walker, C., Fishman, M., and Stainier, D. Y. (2002). Cardiac troponin $\mathrm{T}$ is essential in sarcomere assembly and cardiac contractility. Nat. Genet. 31, 106-110.

Shayakul, C., and Hediger, M. A. (2004). The SLC14 gene family of urea transporters. Pflugers Arch. 447, 603-609.

Smith, C. P., and Fenton, R. A. (2006), Genomic organization of the mammalian SLC14a2 urea transporter genes. J. Membr. Biol. 212, 109-117.

Smith, C. P., Potter, E. A., Fenton, R. A., and Stewart, G. S. (2004). Characterization of a human colonic cDNA encoding a structurally novel urea transporter, hUTA6. Am. J. Physiol. Cell Physiol. 287, C1087-C1093.

Spector, D. A., Yang, Q., Liu, J., and Wade, J. B. (2004). Expression, localization, and regulation of urea transporter B in rat urothelia. Am. J. Physiol. Renal Physiol. 287, F102-F108.
Spector, D. A., Yang, Q., and Wade, J. B. (2007). High urea and creatinine concentrations and urea transporter B in mammalian urinary tract tissues. Am. J. Physiol. Renal Physiol. 292, F467-F474.

Stewart, G. S., Fenton, R. A., Wang, W. Kwon, T. H., White, S. J., Collins, V. M., Cooper, G., Nielsen, S., and Smith, C. P. (2004). The basolateral expression of mUT-A3 in the mouse kidney. Am. J. Physiol. Renal Physiol. 286, F979-F987.

Terris, J. M., Knepper, M. A., and Wade, J. B. (2001). UT-A3: localization and characterization of an additional urea transporter isoform in the IMCD. Am. J. Physiol. Renal Physiol. 280, F325-F332.

Timmer, R. T., Klein, J. D., Bagnasco, S. M., Doran, J. J., Verlander, J. W., Gunn, R. B., and Sands, J. M. (2001). Localization of the urea transporter UT-B protein in human and rat erythrocytes and tissues. Am. J. Physiol. Cell Physiol. 281, C1318-C1325.

Trinh-Trang-Tan, M. M., Cartron, J. P., and Bankir, L. (2005). Molecular basis for the dialysis disequilibrium syndrome: altered aquaporin and urea transporter expression in the brain. Nephrol. Dial. Transplant. 20, 1984-1988.

Trinh-Trang-Tan, M. M., Lasbennes, F., Gane, P., Roudier, N., Ripoche, P., Cartron, J. P., and Bailly, P. (2002). UT-B1 proteins in rat: tissue distribution and regulation by antidiuretic hormone in kidney. Am. J. Physiol. Renal Physiol. 283, F912-F922.

Tsukaguchi, H., Shayakul, C., Berger, U. V., Tokui, T., Brown, D., and Hediger, M. A. (1997). Cloning and characterization of the urea transporter UT3: localization in rat kidney and testis. J. Clin. Invest. 99, 1506-1515.

Uchida, S., Sohara, E., Rai, T., Ikawa, M., Okabe, M., and Sasaki, S. (2005). Impaired urea accumulation in the inner medulla of mice lacking the urea transporter UT-A2. Mol. Cell. Biol. 25, 7357-7363.

vom Dahl, S., and Haussinger, D. (1997). Evidence for a phloretin-sensitive glycerol transport mechanism in the perfused rat liver. Am. J. Physiol. 272 G563-G574.

Wade, J. B., Lee, A. J., Liu, J., Ecelbarger, C. A., Mitchell, C., Bradford, A. D., Terris, J., Kim, G. H., and Knepper, M. A. (2000). UT-A2: a 55-kDa urea transporter in thin descending limb whose abundance is regulated by vasopressin. Am. J. Physiol. Renal Physiol. 278, F52-F62.
Wagner, L., Klein, J. D., Sands, J. M., and Baylis, C. (2002). Urea transporters are distributed in endothelial cells and mediate inhibition of L-arginine transport. Am. J. Physiol. Renal Physiol. 283, F578-F582.

Wang, X., Wu, L., Aouffen, M., Mateescu, M. A., Nadeau, R., and Wang, R. (1999). Novel cardiac protective effects of urea: from shark to rat. Br. J. Pharmacol. 128, 1477-1484.

Wang, Y., Klein, J. D., Liedtke, C. M., and Sands, J. M. (2010). Protein kinase $\mathrm{C}$ regulates urea permeability in the rat inner medullary collecting duct. Am. J. Physiol. Renal Physiol. 299, F1401-F1406.

Xiao, S., Wagner, L., Mahaney, J., and Baylis, C. (2001). Uremic levels of urea inhibit L-arginine transport in cultured endothelial cells. Am. J. Physiol. Renal Physiol. 280, F989F995.

Xu, Y., Olives, B., Bailly, P., Fischer, E., Ripoche, P., Ronco, P., Cartron, J. P., and Rondeau, E. (1997). Endothelial cells of the kidney vasa recta express the urea transporter HUT11. Kidney Int . 51, 138-146.

Yang, B., and Bankir, L. (2005). Urea and urine concentrating ability: new insights from studies in mice. Am. J. Physiol. Renal Physiol. 288, F881F896.

Yang, B., Bankir, L., Gillespie, A., Epstein, C. J., and Verkman, A. S. (2002). Urea-selective concentrating defect in transgenic mice lacking urea transporter UT-B. J. Biol. Chem. 277, 10633-10637.

Yang, B., Ma, T., and Verkman, A. S. (2001). Erythrocyte water permeability and renal function in double knockout mice lacking aquaporin-1 and aquaporin-3. J. Biol. Chem. 276, 624-628.

Yang, B., and Verkman, A. S. (1998). Urea transporter UT3 functions as an efficient water channel. Direct evidence for a common water/urea pathway. J. Biol. Chem. 273, 9369-9372.

Yang, B., and Verkman, A. S. (2002). Analysis of double knokout mice lacking aquaporin- 1 and urea transporter UT-B: evidence for UTB facilitated water transport in erythrocytes. J. Biol. Chem. 277, 36782-36786.

You, G., Smith, C. P., Kanai, Y., Lee, W. S., Stelzner, M., and Hediger, M. A. (1993). Cloning and characterization of the vasopressinregulated urea transporter. Nature $365,844-847$.

Yu, H., Meng, Y., Wang, L. S., Jin, X., Gao, L. F., Zhou, L., Ji, K., Li, Y., 
Zhao, L. J., Chen, G. Q., Zhao, X. J., and Yang, B. (2009). Differential protein expression in heart in UT$B$ null mice with cardiac conduction defects. Proteomics 9, 504-511.

Zhao, D., Sonawane, N. D., Levin, M. H., and Yang, B. (2007). Comparative transport efficiencies of urea analogues through urea transporter UT-B. Biochim. Biophys. Acta 1768, 1815-1821.

Received: 02 April 2012; accepted: 31 May 2012; published online: 26 June 2012.

Citation: Li X, Chen G and Yang B (2012)

Urea transporter physiology studied in

Conflict of Interest Statement: The authors declare that the research was conducted in the absence of any commercial or financial relationships that could be construed as a potential conflict of interest.
Copyright $\odot 2012$ Li, Chen and Yang. This is an open-access article distributed under the terms of the Creative Commons Attribution Non Commercial License, which permits noncommercial use, distribution, and reproduction in other forums, provided the original authors and source are credited. 